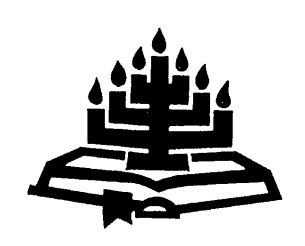

\title{
Die bron van lewensvreugde volgens Psalm 1 en wat dit vir gereformeerde prediking inhou ${ }^{1}$
}

\author{
J.L. Helberg
}

Skool vir Bybelwetenskappe \& Bybeltale

Potchefstroomkampus

Noordwes-Universiteit

POTCHEFSTROOM

E-pos: jaapjlh@absamail.co.za

\section{Abstract \\ The source of joy of living according to Psalm 1 and what it implies for reformed preaching}

The article explores the strong emphasis on joy of living and on the dominating meaning of the Torah, the written Word of God, in Psalm 1 and what it means for the proclamation of the Word in public worship today. For that purpose the relation of Psalm 1 to the rest of the psalms, to the Old Testament as a whole and the New Testament is explored. The finding is that the fulfilment of the New Testament implies Word-driven, Christ-driven and Holy Spirit-driven preaching, i.e. kingdom and covenant preaching. Public worship is God's meeting with his covenant people. The preacher's role is fully one of service and he must confine himself to the interpretation and application of Scripture.

\section{Opsomming}

\section{Die bron van lewensvreugde volgens Psalm 1 en wat dit vir gereformeerde prediking inhou}

Die artikel wil vasstel wat die sterk klem op lewensvreugde en die allesbeheersende betekenis van die Tora, die op-skrifgestelde Woord van God, in Psalm 1 behels en wat dit vandag vir die Woordverkondiging in die erediens inhou. Daarvoor word ook die verhouding van Psalm 1 tot die res van die psalms, tot

$1 \quad$ Hierdie artikel is 'n verwerking van 'n voordrag wat op 10 Februarie 2009 gelewer is by die opening van die Teologiese Skool van die Gereformeerde Kerke in Suid-Afrika in Potchefstroom. 
die Ou Testament as geheel en tot die Nuwe Testament ondersoek. Die bevinding is dat die Nuwe-Testamentiese vervulling Woordgedrewe, Christusgedrewe en Heilige Geesgedrewe prediking, dit is koninkryks- en verbondsprediking, impliseer. Die erediens is God se ontmoeting met sy verbondsvolk. Die prediker vervul geheel en al 'n dienende rol en moet hom bepaal en beperk tot Skrifverklaring en toepassing.

\section{Inleiding}

Hierdie artikel wil vasstel wat die sterk klem op lewensvreugde en die allesbeheersende betekenis van die Tora, die op-skrif-gestelde Woord van God, in Psalm 1 behels. Daar word veral aandag gegee aan die uitsprake "Dit gaan goed met" (asjree; v. 1), die boom wat by waterstrome geplant is (v. 3), God se "ken" van die regverdige, (v. 6) en implisiet, God se absolute bestiering - ook oor die wind (Ps. 1:4). Die verhouding van Psalm 1, as inleidende psalm tot die hele boek sowel as tot die Ou Testament én die Nuwe Testament word ook ondersoek asook wat dit vir die verkondiging van die Woord inhou. Aandag word ook gegee aan die plek van die Skrif in die samekoms van die gemeente en ook aan die inhoud van die Woordverkondiging.

\section{Die plek van Psalm 1 as inleiding tot die boek Psalms en sy verhouding tot die Ou Testament en die Nuwe Testament}

Daar word algemeen aanvaar dat Psalm 1 (en 2) redaksioneel voor aan die psalms geplaas is as inleiding (Ridderbos, 1955:9-10; Miller, 1993:83-92; Seybold, 1998:67-68; Tournay, 1991:7; Wilson, 1992: 132; Brueggemann, 1993:29, 31, 32, 41; vgl. Helberg, 2005:673-694 vir 'n vollediger bespreking van hierdie en ander publikasies; en ook Whybray, 1996, oor die manier om die psalms as 'n boek te lees). Die individuele psalms moet dus nie in isolasie gelees word nie, maar in die konteks van die hele psalmbundel (Reindl, 1981:337338; Loretz, 2002:14). Brueggemann (1991:80-91) sien die eenheid van die psalms as 'n beweging van gehoorsaamheid aan die Woord na lofprysing toe, met Psalm 73 as wendingspunt.

Die plasing van die Tora voorop beklemtoon die psalms as bron van lering eerder as kultus of gebed (vgl. McCann, 1992:120). Dit gaan nie om die Wet soos die Fariseërs en Skrifgeleerdes dit in die tyd van Jesus verstaan het nie. Psalm 1 dwing nie, maar lok die leser. Dit lei die lesers of hoorders tot 'n studie van die leringe van Jahwe tot 'n lewe van geloof (Lombaard, 1999:512). 
Ook Zenger (2000:430-435) oordeel dat die psalms nie 'n kultiese liedereboek is nie, maar 'n leerboek en tegelykertyd instrument vir die heiliging van die alledaagse lewe - ook die lewe buite die tempel en die sinagoge. Die psalms is self die heiligdom waarin God gesoek en geloof word en waarvandaan God se seën en redding uitgaan.

Dit is veral die baanbrekerswerk van Wilson wat die grondslag gelê het vir die bestudering van die psalmbundel as 'n samehangende boek (vgl. Styger \& Human, 2004:291-302 vir 'n oorsig oor sy werk). Tora het in Psalm 1 'n wyer betekenis as net die tien gebooie of Pentateuch. Daar word nie van die Tora van Moses gepraat nie, maar van die Tora van Jahwe (Kratz, 1996:3, 7-11). Die verbindingsfaktor wat die profete, die Pentateuch en die geskrifte, waarvan Psalms deel is, met mekaar verbind, is die Tora (vgl. Ps. 1 met Mal. 3:13-24; Snyman, 2007:795 en ook Weber, 2006:253 wat wys op die verbinding van die Tora in Psalm 1:2 met die einde van die Pentateuch, Jos. 1).

Die psalms beklee 'n belangrike plek in die Skrif en in die reformatoriese kerke. Venter (2001:529) wys op die kontinue lyn tussen Ou Testament en Nuwe Testament. Barnard (2000:215) stel dit duidelik, naamlik dat die psalms in die Ou-Testamentiese tyd 'n wesenlike deel van die liturgie gevorm het. Hierdie liedboek is deur die Heilige Gees geïnspireer en deur die kerke offisieel as die Heilige Skrif erken - dit is kanon. Geen boek van die Ou Testament word in die Nuwe Testament naastenby so dikwels aangehaal as die Psalms nie. Jesus se hele Persoon en sy werk is omring van en deurweef met aanhalings uit die psalms.

In hierdie artikel gaan dit oor die psalms as geheel, gesien vanuit Psalm 1. Behalwe in die Ou Testament het hierdie psalm ook 'n belangrike plek in die Nuwe Testament, hoewel nie direk daaruit aangehaal word nie. Die vorm en inhoud van die bergrede in Matteus vertoon 'n definitiewe analogie met Psalm 1 en teken Jesus as 'n Messiaanse wysheidsleraar, volgens Weber (2006:253). Hy (Weber, 2006:254) sien Psalm 1 (en 2) binne die horison van 'n teologie van die hele Bybel.

\section{Spanning tussen Psalm 1 (en 2) en die res van die psalms oor die harde lewenswerklikheid?}

Op die oog af staan Psalm 1 in spanning, of selfs in botsing, met Psalm 3 e.v. Psalm 1 handel oor die vreugde of geluk en die voorspoed van dié wat die pad van reg en geregtigheid volg volgens die 
Woord van die Here. Baie van die ander psalms handel nie oor voorspoed nie. Inteendeel, dit handel oor onreg, vyandskap en lyding wat die regverdige op hierdie pad ondervind. Hoe moet hierdie spanning of botsing tussen Psalm 1 en die harde lewenswerklikheid verstaan en gehanteer word? Die mens se bestaan en vreugde en die Bybelse godsdiens word wesenlik daardeur geraak. Trouens, die vraag ontstaan of die psalms, met Psalm 1 aan die spits, nie meer beloof as wat dit in werklikheid gee nie. Baie skrywes in dagblaaie en tydskrifte wys dat baie mense inderdaad vandag só oor die Bybelse godsdiens voel. Hulle is teleurgestel in hulle verwagting.

Die feit dat Psalm 1 (en 2) as inleiding, doelbewus, direk voor Psalm 3 e.v. geplaas is, wys dat daar nie 'n botsing tussen hulle gesien moet word nie. Die inhoud van Psalm 1 getuig ook van iets anders. Die psalm beloof nie 'n paradyssituasie nie. Inteendeel, hier word juis gepraat van goddeloses en goddeloosheid binne die gelowige se wêreld en 'n antwoord word gegee op die gelowiges se worsteling met die probleem waarom God onreg toelaat.

Psalm 1 sê verder dat lewensvreugde nie werklik voortspruit uit voorspoed of uit wat 'n mens doen nie, maar uit die bron of dryfkrag daarvan. Die psalm gee nie 'n rasionele oplossing vir die probleem van onreg en lyding nie, maar vra oorgawe in 'n mens se vertroue op God - vertroue dat Hy wat allesbeheersend en sorgend teenwoordig is, 'n mens ken en met jou meeleef. Vertroue lei die gelowige tot 'n vreugdevolle, verwagtingsvolle en toekomsgerigte bestaan. Brueggemann (1991:80-91) wys daarop dat Psalm 73 byna letterlik, maar ook teologies en kanonies sentraal in die Psalms staan. Die Psalmdigter begin deur dít wat Psalm 1 verkondig, te bevestig. Dan gaan dit egter oor na die twyfel wat die harde werklikheid daaroor bring. Die digter keer egter weer na die geloofsbenadering terug: "totdat ek in die heiligdom ingegegaan en besef het wat die uiteinde van die goddeloses is" (Ps. 73:7). In die gebruiklike plek van aanbidding waar Israel se geheue vasstaan, kry die digter weer 'n blik op die werklikheid. Om met God self te doen te hê, is wat uiteindelik saak maak. Net soos in Psalm 1 is dit in Psalm 73 nie materiële seën wat waardevol geag word nie, maar God self. Dit open die weg vir selfverloënende lofprysing. Die literatuur van die psalms benadruk nie alleen die vorm van die Bybelboek nie, maar van Israel se geloof en hulle lewe. 


\section{Die vreugdeboodskap van die psalms}

Die psalms, saamgetrek in Psalm 1 as die inleiding, sê dat God se openbaring ' $n$ vreugdevolle boodskap aan die mens inhou. Psalm 1 begin met die mens, met die goeie en vreugde vir die mens. ("Dit gaan goed met die mens wat ... in die Woord van die Here sy vreugde vind", Ps. 1:1-2.) Dié psalm is egter nie mensgesentreerd of mensgedrewe nie, maar koninkryksgerig en koninkryksgedrewe; anders gestel, Godgerig en Godgedrewe. Die psalm se woorde oor goed gaan en vreugde is by voorbaat ' $n$ antwoord op die probleem waarmee baie psalmdigters worstel, naamlik oor lyding en onreg, oor waarom dit met die goddeloses so goed gaan en met die regverdiges sleg.

Psalm 1 as inleiding tot die psalms as 'n saamgestelde eenheid, sê dat ' $n$ mens hom nie deur hierdie skynbare onreg moet laat verlei om ook soos mense te maak wat hulle eie kop volg nie. Die regverdige moet hom laat lei deur God se wil of openbaring, soos in sy opgeskrewe Woord (Tora) (Miller, 1986:83) - dan gaan dit met 'n mens waarlik goed; dan het hy lewensvreugde en is hy waarlik gelukkig ("maar wat in die Woord ... van die Here sy vreugde vind"). 'n Mens moet hom gewillig oorgee aan God se wil, sy Woord. Hy moet toelaat dat die Woord van die Here sy hele denke, sy dag en nag, sy hele bestaan, al sy tyd, vul.

Die vreugdeverkondiging straal verder uit die lofsegging wat in baie psalms voorkom en wat ook die struktuur van die boek kenmerk. Dit kom aan die einde van elke bundel en in die psalms aan die einde van die boek as 'n geheel voor. Die psalms bevat 'n blye verkondiging, of evangelie, soos heel aan die begin van die Bybel, voor die sonde van die mens (vgl. die grond vir lewensvreugde by die skepping in Gen. 1 en 2: "dit was goed", "been van my been"). Vreugde kenmerk verder die deurlopende verkondiging van die Ou Testament en in besonder die vervulling deur Jesus Christus in die Nuwe Testament (Matt. 1). In die reformatoriese godsdiens beklee lewensvreugde eweneens 'n belangrike rol (vgl. byvoorbeeld die Heidelbergse kategismus wat begin met 'n mens se enigste troos).

Die vreugdeverkondiging in Psalm 1 trek saam in God se persoonlike betrokkenheid en sorg, soos in die volgende gesien kan word: die vreugdevolle uitroep, "Dit gaan goed met" (asjree, v. 1), die boom wat by waterstrome geplant is (v. 3), God se "ken" van die regverdige, (v. 6), en implisiet, God se absolute bestiering - ook oor die wind (1:4). Die bespreking wat volg, sal toon dat dit in Psalm 1 
nie bloot om lewensvreugde gaan nie, maar veral om die bron (Bron) daarvan.

\section{5. 'n Positiewe lewensinstelling deur bevryding en 'n teosentriese benadering - asjiree (Dit gaan goed met)}

Psalm 1 praat van 'n positiewe lewensinstelling, maar nie 'n idilliese een nie; nie volgens menslike begeertes of verwagtings nie. Die psalm bied geen grond vir 'n voordeelgodsdiens nie, anders as die oorheersende ideologie van ons kultuur wat toegewy is aan kontinuïteit en sukses en aan vermyding van pyn, lyding en verlies (Brueggemann, 2002:14). Dit gaan in hierdie psalm om 'n positiewe lewensinstelling binne die werklikheid van 'n stukkende, sondige wêreld vol vyandskap. Die psalmdigter praat wel van 'n bevrydende situasie, en tipies Ou Testament, nie net geestelik nie, maar in terme van konkrete voorspoed. In die voorspoed gaan dit egter ten diepste om vrugbaarwees, in die sin van diensbaar wees. Hierdie benadering bied ook die grond vir vreugde en lofuiting, soos in baie psalms en ook in die afsluiting van die vyf onderdele, al is daar prakties (skynbaar) niks om oor dankbaar te wees nie (bv. in Ps. 41).

Die woord asjree (dit gaan goed met) waarmee Psalm 1 begin en Psalm 2 afsluit, kom 45 keer in die Ou Testament voor, veral in die psalms (26 keer) en wysheidsliteratuur (8 keer; Saebe, 1971:258259). Asjree is nie 'n wens of belofte nie, maar 'n vreugdevolle uitroep en begeesterde konstatering (Feststellung): "Hoe gelukkig is die man tog!" (Kraus, 1972:3). Die "goed gaan" of gelukkigheid en die vreugde van die gelowige spruit voort uit die genadige wilsopenbaring in die Woord (Saebe, 1971:258-259).

Die toestand wat deur asjree aangedui word, kan verskillend van aard wees, soos die besit van kinders, skoonheid, om wysheid te vind, ensovoorts, maar asjree sluit ook in dat so 'n persoon nie die vaste verordeninge van God verbreek nie, maar hom daaraan onderwerp. Die gelukkigwens, anders as 'n seën, vereis bepaalde dade van die gelowige, maar die geluk of vreugde hang af van die Here se optrede, volgens sy verkiesing (Ps. 33:12) en onderwysing (Ps. 94:12).

Weber (2008:215) wys daarop dat die gelukkigprysings in die psalms 'n strukturele sowel as teologiese betekenis het. Psalm 1, en daarmee die hele psalmboek, begin met asjree, en Psalm 2, wat saam met Psalm 1 'n inleiding op die boek vorm, sluit daarmee af. So word die (Mosaïese) Tora-wysheid met die (Dawidies-Salomo- 
niese) koningskap verbind. Volgens Botha (2005:200-202) was die redakteur van die psalms se benadering dat Jahwisme 'n teokratiese gemeenskap, nasionaal en internasionaal, veronderstel en as noodsaaklik geag het. Hoofsaak in elk geval is dat die Woord van die Here die allesbeheersende is. Die feit dat Psalm 1 met ' $n$ stelling begin, met ' $n$ voorbeeld van 'n waarlik gelukkige persoon, of ' $n$ uitnodiging om so te wees, moet verstaan word teen die agtergrond van die psalmdigters se probleem met onreg en lyding. Die psalmdigters benader die lewe en gang van sake teosentries: God is in beheer. Maar hulle worstel dikwels met die vraag waarom Hy onreg en lyding toelaat. 'n Gelowige vind tog nie daarby baat nie? Psalm 1 benader die saak nog meer teosentries met die benadering om nie op lewensvreugde te konsentreer nie, maar op die lewegewende en standhoudende bron daarvan. Die antwoord op die probleem van lyding en onreg en ware voorspoed lê in volledige oorgawe aan God se wil en bestiering, in sy "ken" van die mens se pad.

'n Mens se kennis van die werklikheid of sy kennis van die Woord bied nie die antwoord of oplossing nie, maar dat die Woord van Jahwe hóm ken. Dit hou in dat Jahwe hom ken in sy sorgende liefde, soos Psalm 1 afsluit, en dat hy alles in die hand van Jahwe laat. Hy laat per slot van sake die goddelose vernietig word. Dit is trouens nie die mens wat met God op pad is nie, maar God wat met hom op pad is. Daarom lewe die gelowige 'n verwagtingsvolle bestaan en sien hy selfs uit na 'n eskatologiese toekoms (Ps. 1:5). Psalm 2, wat saam met Psalm 1 die inleiding vorm, gee dit 'n messiaanse kleur (vgl. ook Rösel, 1999:155-157 oor die messiaanse redaksie van die psalms).

Kraus (1972:8) sê dat die sakraalregtelike instellings wat in Psalm 1 vermeld word, die empiriese werklikheid van die kulties-sakrale transendeer en dit transparant maak vir wat die hele bestaan omvat en na die eindtyd heenwys. Die voorgaande bespreking wys dat dit uit die genadige wilsopenbaring van God is wat die "goed gaan" of gelukkigheid" en die vreugde voortspruit.

\section{Soos 'n boom wat by waterstrome geplant is}

Die vreugdeuitroep asjree dui daarop dat dit nie is wat die regverdige teweeg bring, wat 'n oplossing bied nie, maar sy afwysende instelling teenoor diegene hulle eie kop volg en hulle eie pad loop, en sy instelling van algehele oorgawe aan die Woord van Jahwe. Hierdie situasie is soortgelyk aan die ontdekking van die hervormer Martin Luther dat bevryding nie uit menslike inspanning voortkom nie, maar alleen deur die geloof in Christus se verlossingswerk. 
Geloof bewerk nie die verlossing nie, maar aanvaar net God se verlossingswerk in Christus. Om dag en nag die Woord te oordink, dui nie op menslike kreatiewe omgang daarmee of 'n menslike bydrae nie, maar dat 'n mens hom volledig by die wil of Woord van Jahwe neerlê en hom daardeur laat lei. Dan ontdek hy dat dit inderdaad die Woord van Jahwe is waarmee hy te doen het; die Woord wat met hom besig is. In der waarheid was Jahwe self alreeds met hom besig.

Wanneer 'n mens dag en nag die Woord oordink, is hy soos 'n boom by waterstrome. Die boom staan nie maar vanself daar nie, maar is daar "geplant", sê die psalm. Dié woord word in tuinboukunde gebruik in verband met die oorplanting van wingerde en vrugtebome (Eseg. 17:7-8; Taylor, 1955:21). Geplant beteken hier om oorgeplant te wees soos 'n boom wat van 'n droë vlakte na die waterkant verskuif is (Miller, 1986:83). Daar is dus 'n hand agter die boom en dus ook agter die gelowige se optrede. Voordat hy so met die Woord omgaan, is daar reeds kweking, beplanning en sorg aan hom bestee.

Die bestaanwyse van die regverdige, in besonder sy allesbepalende liefde en lus vir die Tora, kom uit die lewende mededelingskrag en daadkrag van die Tora self (Ps. 19b; 119; Kraus, 1972:10).

In Psalm 1 is daar wel sprake van 'n menslike handeling in verband met die Woord, maar die menslike optrede koop of ruil nie God se optrede nie, of gee nie die vonk daarvoor nie, maar is die vrug van God se optrede. Dit is nie werklik die leser wat homself met die Woord voed, of die prediker wat die hoorders daarmee voed nie. Die prediker bring die Woord wat hom en hulle voed. Hier word dus op 'n subtiele manier ' $n$ verskil gemaak tussen menslike daadkrag of menslike bydrae enersyds, en oorgawe aan die Woord andersyds (soortgelyk aan die waarskuwing in Psalm 127 om nie op menslike inspanning peil te trek nie: "As die Here die huis nie bou nie ...").

Dit gaan dus met 'n mens goed wanneer jy jou voluit laat beheers deur die Woord van God waarvolgens God regverdig regeer, die gelowige onder sy sorg het en hom ware, innerlike lewenskrag gee. Die water voed te alle tye die wortels van die boom, sodat hy "op sy tyd", dit wil sê reëlmatig en bestendig, sy vrug voortbring en die blare nie verwelk nie. Die verbinding met die lewenselement verseker in elke opsig 'n "vrugbringende bestaan" (Kraus, 1972:6).

God is in volle beheer en Hy sorg, al gaan onheil skynbaar ongestoord voort. Die gelowige moet wel bereid wees om alleen te 
staan in die stryd vir reg. Die regverdige vertoon hierdie trekke van die oerbeeld van eensaamheid, terwyl die goddeloses in hulle veeltalligheid die karakter van 'n massa perditiones (verlorenes) vertoon (Kraus, 1972:7). Die uiteindelike vrug sal dit uitwys. Die resultaat is nie 'n kwessie van 'n meganiese oorsaak en gevolg nie, maar van persoonlike Goddelike bestiering. Wie geheel en al aan God oorgegee is, ontvang deur God se Woord ware lewenskrag en groei; die goddeloses daarenteen, verloor ware lewenskrag, raak verdor soos kaf wat deur die wind weggewaai word (Ps. 1:4).

In Psalm 1 se antwoord op die probleem van onreg en lyding is 'n fyn onderskeiding of wending in die benadering van voorspoed, naamlik dat voorspoed nie gesien word as vrugte pluk nie, maar as "vrugte dra". Die psalmdigters beny die goddeloses hulle voorspoed. Psalm 1 sê die regverdige hét voorspoed, maar in die sin van 'n vrugbare lewe. Dit beteken diensbaar wees aan God se wil met 'n mens se lewe; aan God wat die regverdige maak soos 'n oorgeplante en vrugdraende boom in hierdie stukkende en sondige wêreld.

Die psalms kry finale beslag in die ballingskap- en na-ballingskapse tyd. Psalm 1 as inleiding moet dus ook gesien word vanuit die ballingskapslyding wat die verbondsvolk Israel getref het. Ballingskap was so goed soos die dood van Israel. Israel het byna alles verloor, hulle was sonder land en alles wat daarmee saamgaan. Hulle was weggevoerdes. As die oorwonnenes en onderhoriges in 'n vreemde land was hulle sonder burgerregte. Israel het nie meer die gewone liturgiese byeenkomste gehad nie (Ps. 137). Wat hulle wel gehad het, was die geskrewe Woord van Jahwe. Dit was hulle stukrag.

Uit die voorafgaande is dit duidelik dat dit by die gelowige wat hom aan die Woord wy, gaan om 'n lewensinstelling wat nie net Godgerig is nie, maar Godgedrewe. Die gelowige kan nie uit homself op die Woord gerig wees nie. Dit gaan vir hom ook nie om vrugte van voorspoed te pluk nie, maar om vrug te dra, diensbaar te wees.

\section{God se "ken" van sy gelowiges en die lot van die goddeloses}

lemand wat gewillig oorgegee is aan God se wil soos dit in sy Woord geopenbaar is, word en is reeds deur God onder sy sorg geneem. God "ken" so iemand en gee hom lewensvreugde. Die woord "ken" (jada) in die mededeling: "Jahwe ken die weg van die regverdiges", dui hier op 'n intieme verhouding en het die betekenis 
om iemand aan te neem, iemand met besondere meelewing te vergesel, hom naby te wees en vir hom te sorg (Ps. 34:16 e.v.).

Hierdie werkwoord behoort nie tot die sfeer van betragting nie, maar tot dié van kontak (Kraus, 1972:9). Jahwe ken die regverdige in 'n verbondsverhouding. 'n Verbondsverhouding impliseer verantwoordelikheid, individueel sowel as kollektief. Psalm 1 is individueel gerig, maar ook binne ' $n$ verbondsbenadering, soos gesien in die verwysing na die vergadering van die regverdiges in vers 5 . Sonder hierdie verhouding is iemand op die weg van die goddeloses wat vergaan.

Godgedrewenheid word ook in Psalm 1:4 geïmpliseer teenoor die goddeloses wat soos kaf is en deur die wind uitmekaar gewaai word. Dit is dié wat hulle eie kop volg en hulle nie aan God steur nie. Hulle verag die Tora van Jahwe en het hulle eie lewensprinsipe en beginsels (Kraus, 1972:4). Hulle pluk die vrugte van hulle eie optrede en kan net hulleself verwyt. So stel die laaste vers dit ook: "die pad van die goddeloses lei tot ondergang". Maar al lyk dit of God hierin passief is, bly die Goddelike heerskappy en optrede tog geld.

Hierdie vers laat dink aan 'n louteringsgerig wat oor die volk sal kom, soos in Jesaja 1:25 e.v. waarin die goddeloses weggevaag word. Dit dra wel nie die karakter van die messiaanse eindgerig soos byvoorbeeld in Maleagi 3:3 beskryf word nie, maar is tog nie streng hiervan te skei nie (Ridderbos, 1955:16). Dit strek wel oor die huidige bedeling heen, veral gesien in verbinding met Psalm 2 met sy messiaanse inslag.

Hier in Psalm 1:4 mag dit lyk asof dit wat met die goddeloses gebeur, net natuurgedrewe is, in die sin dat dit net 'n kwessie van oorsaak en gevolg is. In werklikheid, so sê die psalm egter implisiet, is God in volle beheer. Hy bestier ook die natuurlike verloop van dinge. Dit is Hy wat die wind laat waai. Psalm 19 besing hoe God Hom in die natuur openbaar. In God se bestiering van alles speel die Gees 'n belangrike rol, al is dit 'n half verskuilde rol, soos in Genesis 1. In Genesis 1:2 word gemeld dat die Gees van God oor die waters gesweef het, 'n sekere aktiewe rol daarin gespeel het, maar verder word die Gees nie weer genoem nie.

Die beeld van kaf en Gees (ruah) kom meermale voor (Ps. 35:5; 83:14; vgl. ook Job 21:18; Jes. 17:13; 29:5; 41:16). Hoewel nie direk nie, word implisiet gestel dat die loon van die regverdige en die straf van die goddeloses deur Goddelike optrede teweeg gebring word 
(Ps. 1:6). Albei, beloning en straf, is die gevolg van 'n mens se lewenswyse, maar dit is nie die noodwendige gevolg van oorsaak en gevolg nie. Dit word teweeg gebring deur 'n daad van God (Oesterley, 1959:121; vgl. ook Prinsloo, 1984:15; Toombs, 1972:261).

\section{Die werking van die Gees (ruah) in die psalms}

Ruah word soms verbind met God se bevel (asem/gees uit sy mond), en raak veral die Godgesentreerdheid en Godgedrewenheid waaroor dit hier gaan. Psalm 33:6, 9 lui: "Deur die woord van die Here is die hemele gemaak, deur sy bevel al die hemelliggame, ... want Hy het gepraat en dit was so, Hy het beveel en dit was daar". Psalm 1:4 laat ook dink aan Jesaja 40:7: "gras verdor en blomme verwelk as die Here sy wind (ruah; OAV: asem) daaroor laat waai ".

In Psalm 51 en 139 word oor die Gees van God gepraat, veral in verband met God se persoonlike, innerlike, ondersoekende en lewegewende werking in 'n mens (Ps. 51:12-13: "Skep vir my 'n rein hart, o God, vernuwe my gees en maak my standvastig. Moet my tog nie van $U$ af wegdryf en u Heilige Gees van my af wegneem nie."; Ps. 139:1: "Here, U sien dwarsdeur my, U ken my."; Ps. 139:7: "waarheen sou ek gaan om u Gees te ontvlug ...").

Hierdie Skrifgedeeltes praat ook van die Gees se korrektiewe of herskeppende werking (Ps. 139:23-24: "Deurgrond my, o God, deurgrond my hart, ondersoek my, sien tog my onrus raak. Kyk of ek nie op 'n verkeerde pad is nie en lei my op die beproefde pad."; Ps. 143:10:."Leer my om $u$ wil te doen, want $U$ is my God! Laat $u$ goeie Gees my op 'n gelyk pad lei".).

Ook Jesaja, Jeremia en Esegiël wat oor die ballingskap handel, waarin die psalms 'n belangrike beslag gekry het, ken 'n belangrike rol toe aan die Woord (en Esegiël aan die Gees) in verband met Israel se situasie. Daarmee word die Godgedrewenheid van die gebeure en situasie beklemtoon (Jes. 40:6-8, 9-11, 13; 42:1, 7; Jer. 31:31-34; Eseg. 36:26-27; vgl. ook Becking, 2004:263 oor die verbond en die Wet as simbole van hoop, synde elemente van persoonlike geloof wat individuele verantwoordelikheid impliseer; dit is 'n hoopvolle geloof wat nie op individuele ervaring gegrond is nie, maar op die verhouding tussen God en sy volk deurdat Hy die Wet op hulle harte skrywe).

Die werking van die Gees in die Ou Testament getuig van innerlikheid en nabyheid, maar beslis nie van 'n vereniging tussen God en die mens nie. Daar bly 'n wesenlike verskil tussen Skepper en 
skepsel. Die Psalmbundel werk op na lof aan God in sy grootheid en majesteit. Al die fokus is op Hom en lof gaan aan Hom. Die mens staan nie in die middelpunt nie, maar God. Die mens staan ook nie saam met God in die middelpunt nie, maar God wat geloof word. Dit is die sin van die mens se bestaan; daarvoor het hy die lewensasem ontvang (Ps. 150:6). Die Gees en Woord maak die mens vol van die ware gees en asem om God te loof.

Ware bevryding, vreugde en voorspoed kom deur oorgawe aan God. Die boek Job wys veral hoe Bybelse godsdiens 'n Godgesentreerde benadering vereis. Dit gaan om die onvoorwaardelike erkenning van God se soewereiniteit en vrymag. Dan kom 'n mens tot die ontdekking van sy persoonlike nabyheid (vgl. Job 38-41 met 42:1-6). Oorgawe lei tot vreugde en lof. Dit kom duidelik daarin uit dat elk van die vyf bundels en die psalms as geheel afsluit met 'n lofsegging, selfs al lyk dit of die betrokke psalm self geen aanleiding daarvoor bied nie. Selfs in die moeilikste omstandighede, sonder dat daar 'n teken van voorspoed is, loof die gelowige God (Ps. 41).

\section{Die vervulling van die Ou Testament deur die koms van Christus en die Heilige Gees}

Die koms van Christus hang ten nouste saam met die verkondiging van vreugde. In en deur Christus het die Christen deel aan die gelukkige bestaanswyse van die nova creatura van die regverdige, sy bestaan as nuwe skepsel (Kraus, 1972:10). Christus is die weg/ pad en die waarheid en die lewe, die Immanuel, God by ons. Die koms van Christus staan ook in noue verband met die Woord, synde vervulling van die Ou-Testamentiese verkondiging (vgl. Christus se geboortegeskiedenis in Matt. 1:22; 2:6, 15, 18; vgl. verder Greidanus, 1999:1-32). Christus sê dat Hy nie gekom het om die Wet of die profete ongeldig te maak nie, maar om hulle hulle volle betekenis te laat kry (Matt. 5:17). Verder sê Hy dikwels: "Daar staan geskrywe", of "volgens die Skrif(te)". Die Skrif bly dus steeds 'n allesbeheersende plek inneem. Dit geld ook vir die erediens. Dit is 'n leemte by Leuschner en De Klerk (2007:259-297) oor basisteoretiese beginsels vir die atmosfeer in die erediens in 1 Korintiërs 11-14 dat hierdie aspek nie aandag kry nie. In 1 Korintiërs 14:21 word uitdruklik verwys na dit wat in die wet geskrywe staan (Jes. 28:11-12 en Deut. 28:49). (Vgl. egter ook De Klerk \& Janse Van Rensburg, 2005:3-5 in verband met die prediking.)

Die koms van Christus staan ook in noue verband met die Heilige Gees. Die uitstorting van die Heilige Gees word in Handelinge 2:16- 
21 gesien as 'n vervulling van die profesie van Joël. Christus en die Heilige Gees moet nie onafhanklik van mekaar gesien word nie. Christus is gebore deur die Gees, toegerus deur die Gees en uit die dood opgewek deur die Gees (Matt. 1:20; 3:16; Efes. 1:19-20).

Die koms van Christus en die Heilige Gees is ten nouste verbind aan die Woord. Christus is trouens die Woord wat mens geword het (Joh. 1) en Hy werk deur die Gees (Joh. 3:34: "God het Hom immers gestuur, en Hy spreek die woorde van God, want God gee Hom sy Gees sonder enige beperking.").

Christus het veral met die versoeningswerk vir die gelowige te doen, en die Heilige Gees veral met die korrektiewe en lewewekkende werking in die mens (Gal. 5:16-17: "Laat julle lewe steeds deur die Gees van God beheers word, dan sal julle nooit swig voor begeertes van julle sondige natuur nie. Wat ons sondige natuur begeer, is in stryd met wat die Gees wil, en wat die Gees wil, is in stryd met wat ons sondige natuur begeer.").

Die Heilige Gees het ook veral te doen met ons vryspraak, geloofsvertroue en toerusting (Gal. 5:5: "Wat ons betref, deur die werking van die Gees is dit ons hoop en verwagting dat ons deur te glo, vrygespreek sal word."; 1 Kor. 1:13: "In Christus het die Heilige Gees wat deur God belowe is, julle as sy eiendom deur God beseël. Die Heilige Gees is die waarborg dat ons ook verder sal ontvang wat God belowe het."; Rom. 5:5: "liefde deur die Gees uitgestort in julle harte").

In die Ons Vadergebed word die Gees nie genoem nie, ook nie Christus nie en ook nie die Woord nie. Tog word dié gebed deur die Gees, Christus en die Woord beheers. Die gelowiges bid hierdie gebed in sy Naam, op sy bevel, en dit word deur die Heilige Gees in die mens se hart gelê, sodat hy Hom as Abba, Vader, aanspreek (Gal. 4:6).

\section{Christus-, Woord- en Geesgedrewe prediking}

Hoewel Psalm 1 nie oor Christus of die Heilige Gees praat nie, anders as in verband met die Woord, word met Psalm 1 as uitgangspunt oor Christus- en Heilige Geesprediking gehandel. Die rede hiervoor is Psalm 1 se Godgesentreerde en Godgedrewe benadering en alles wat daarmee saamhang en daaruit voortvloei. Dit kan in die res van die psalms sowel as die Ou Testament en die Nuwe Testament gesien word (vgl. ook die verwysings na Venter, 
2001:529; Barnard, 2000:215; en Weber, 2006:253, 254 in punt 2 hierbo).

Ondanks geluide dat die tyd daarvoor eintlik verby is, beklee prediking ' $n$ belangrike plek in die reformatoriese benadering (De Klerk, 1977:10-120; De Wet, 2009:28), in besonder die Gereformeerde Kerke. Dit neem trouens ' $n$ wesenlik belangrike plek in die Bybelse verkondiging in (Rom. 10:14-15). Die prediking is trouens die primêre opdrag van die Here Jesus Christus aan sy kerk (Matt. 28:19). Ware Woordprediking verkondig Christus as vervuller van die OuTestamentiese verkondiging van verlossing deur geloof in God se genadige vryspraak, nie deur mense se eie manier van doen nie (Rom. 9:30-10:17). Suiwer verkondiging van die Woord is een van die merktekens van die ware kerk (NGB art. 29). Die sentraliteit van die prediking in die liturgie wortel in die reformatoriese sola Scriptura (die Skrif alleen) en die sola gratia (die genade alleen") (De Klerk, 1977:9-10).

Daar moet allereers vasgestel word wat God in 'n bepaalde Skrifgedeelte doen (Greidanus, 1970:146). Die prediker moet hom aan die Woord bind en as herout van Christus net dit verkondig wat die Skrif verkondig. Die Skrif is meer as ' $n$ historiese weergawe; dit is God se Woord wat selfs nou tot die mens kom en hom tot geloof en bekering roep. God laat sy koninkryk deur die verkondiging van sy Woord kom. Die prediker moet slegs die Woord bedien (Greidanus, 1970:161, 199, 230-232). Die Psalms, met Psalm 1 as inleiding, wys dat tekste of Skrifgedeeltes in hulle groot Skrifverband of Skrifkonteks benader moet word. So 'n benadering bring 'n mens by ware vreugdeverkondiging, meer bepaald die bron van vreugdeverkondiging. Dit is nie 'n statiese bron waaruit 'n mens self moet skep nie, maar 'n skeppende bron, een met dryfkrag. Psalm 1 verkondig ' $n$ lewe uit God en sy lewewekkende Woord, 'n lewe van oorgeplant, hernuwe wees, van selfondersoek en bekering, van hoop en uitsig en van vrugdra. 'n Lewe van diensbaarheid uit liefde vir God en jou naaste. So 'n verkondiging skep 'n atmosfeer van vertroue, dankbaarheid en oorgegewenheid in vreugde en gehoorsaamheid en lei tot 'n verwagtingsvolle lewe. Dit geld vir hierdie lewe en ook vir wanneer Christus weer kom. Alles lei tot 'n lewe van lof aan God, selfs in die moeilikste omstandighede.

Veral Nuwe-Testamentiese gelowiges, en bepaaldelik predikers, het te doen met die evangelie, die blye boodskap, lewensvreugde, veral met die Goddelike bron en doel daarvan. Dit gee 'n Bybelse visie vir 'n mens se geloofslewe in 'n tyd waarin daar 'n sterk neiging is om 
kerkwees aan mensgedrewe optrede te meet in plaas van Woorden Geesgedrewe optrede, een van selfondersoek en bekering.

Vandag word soms gehoor (De Wet, 2009:28) dat Gereformeerdes se prediking te intellektueel of verstandelik is en net kennis meedeel. Dit doen nie 'n oproep tot aktiwiteit nie en het nie genoeg hart nie. Gereformeerde predikers moet hulself eerlik aan hierdie kritiek toets. Die Psalms en die res van die Skrif vra in elk geval nie so 'n prediking nie. Ondanks die belangrikheid van die geskrewe Woord verkondig die Skrif nie 'n boekgodsdiens nie. 'n Mens word deur die Skrif voor die Woord as Woord van die Here gestel en daarmee voor die Here self gestel. Dit is omgang met God deur die Woord. Die psalms verkondig God se persoonlike betrokkenheid en sorg. Omgang met die Woord vra algehele oorgawe aan die Woord, sê Psalm 1. Die Woord bring 'n mens tot die besef dat jy soos 'n oorgeplante boom is wat deur 'n lewende bron, 'n lewewekkende bron, gevoed word.

Die prediker moet dus nie óór die Woord of óór God preek nie, maar moet die Woord laat praat sodat God in sy Woord aan die woord kom (vgl. ook De Wet, 2009:28-29 oor die predikant as bedienaar van die Woord). 'n Ware preek is dus nie net op die Woord of op God gerig nie, maar deur die Woord gedrewe. (Vgl. ook Venter, 2004:491 dat die Woord van God nie toepaslik gemaak hoef te word nie, maar toepaslik gepreek moet word, en dat toepassing dwarsdeur, geïntegreerd en kongruent met die verklaring in die preek moet konkretiseer.) 'n Preek is dus ook nie 'n kerklike lesing nie, maar is verkondiging. Prediking is deel van die erediens, dra 'n amptelike karakter as deel van God se ontmoeting met sy volk. Dit geskied in God se besondere teenwoordigheid: dit moet voor God gestel wees in 'n atmosfeer van heiligheid en gewydheid (Leuschner \& De Klerk, 2007:278) soos in Jesaja 6:3 genoem word ("Heilig, heilig, heilig is die Here die Almagtige! Die hele aarde is vol van sy magtige teenwoordigheid"; vgl. De Klerk, 1977:14-16). Die gemeente kom om te luister en toegerus te word vir hulle lewensroeping.

Die Woord stel die prediker onder die dissipline van bedienaar voor God, bedienaar in die verklaring van Gods Woord. Dit is misplaas om met lighartigheid, grappies, eie ervaring, ensovoorts die Woord te probeer stimuleer om ingang te vind. So 'n optrede val God as 't ware in die rede en is teen die grein van God se soewereine optrede soos Psalm 1 leer. So 'n optrede is nie 'n benadering van Godgedrewenheid waarin God die groot Subjek is nie. (Vgl. ook Kruger \& Venter, 2002:359, 364 oor die diensknegsgestalte van die prediker en dat hyself nooit aan die woord moet kom nie.) 
Heilige Geesprediking is veral belangrik omdat dit die evangelieverkondiging as gawe en eis bymekaar bring (vgl. ook Venter, 2001:530 oor die indikatief en imperatief van prediking). Daar hoef dus nie nóú oor die gawe en dán weer oor die eis gepreek te word nie, maar oor God se handeling ín ons en die vrug wat daaruit voortvloei, naamlik ons handeling. Daar word gewoonlik in Gereformeerde preke ten regte sterk klem gelê op Christus se soenverdienste vir ons. Dit gaan oor wat Christus vír ons gedoen het. Wat Christus deur die Heilige Gees ín ons doen, word egter dikwels nie in die preek uitgewerk nie. Daar word dus oor Christus as die gekruisigde gepreek, maar nie ook as die Een wat uit die dood opgestaan het en deur Wie ons tot 'n nuwe lewe opstaan nie. Die gebeurtenis van die verlede op Golgota word gepreek, maar nie dit wat nou deur die Gees in ons gebeur nie. Die wesenlik belangrike persoonlike verhouding tussen God en ons, bly dan ongepreek (vgl. die Heidelbergse kategismus daaroor dat God in die volkomenheid van die koninkryk alles sal wees in almal - nie bloot alles oor almal nie).

In Heilige Geesprediking wys die prediker veral hoe die mens as sondige wese negatief ingestel is teenoor wat in die tema gestel word. Heilige Geesprediking stel dus veral die ondersoekende, regstellende, korrigerende, bekerende werking van die Heilige Gees in verband met die tema aan die orde. Dit laat 'n mens jou in jou sondige self ontdek en dring jou om jou gesindheid te verander.

Terselfdertyd word 'n mens deur die Gees oortuig van God se genade en vergifnis en word 'n begeerte by jou gewek om vir God te lewe deur Hom en jou naaste lief te hê. So word nie net 'n beroep op 'n mens se verstand gedoen nie, maar ook die gevoel, wil en begeerte word aangeroer. (Vgl. ook De Klerk \& Smit, 2002:108, 117122 oor die werking van die gees en die verstand in die erediens.) Sodoende beleef 'n mens Christus as "God by ons" en beleef jy God as Vader in Wie se diens en sorg jy is.

Op 'n spontane manier kom dit na vore dat God self alles vir die mens se redding doen en dat Hy self sy koninkryk laat kom, ook in jou. So word die gelowiges begeester om uit dankbaarheid voluit diensbaar te wees.

In die lig van die psalms moet die prediking die hele volle lewe omvat (vgl. die vrugbare boom): 'n mens se daaglikse doen en late, jou roeping in die samelewing en in verband met die ekologie, met ander woorde jou roeping in stoflike en geestelike betrokkenheid by ander. 


\section{Samevatting en gevolgtrekking}

Psalm 1 as inleiding tot die Psalms, en daarmee tot die Psalms as geheel sowel as tot die Ou Testament, stel 'n sterk Godgesentreerde en Godgedrewe benadering as die bron van lewensvreugde in hierdie stukkende wêreld. Lewensvreugde setel in diensbaarheid aan die wil van God, soos geopenbaar in sy op-skrif-gestelde Woord. Die Nuwe-Testamentiese vervulling impliseer 'n Woordgedrewe, Christusgedrewe en Heilige Geesgedrewe prediking, verkondig die absolute heerskappy en inisiatief van God en vra koninkryksen verbondsprediking. Verder veronderstel dit die allesbeheersende plek van die Skrif in die erediens as ontmoeting van God met sy verbondsvolk. Hierdie ontmoeting vereis 'n gewyde atmosfeer. Die prediker vervul in hierdie ontmoeting 'n volkome dienende rol en moet hom bepaal by en beperk tot Skrifverklaring en toepassing.

\section{Geraadpleegde bronne}

BARNARD, A.C. 2000. Die besondere betekenis van die psalms in die Christelike kerk. Skrif en kerk, 21(2):214-227.

BECKING, B. 2004. Between fear and freedom: essays on the interpretation of Jeremiah 30-31. Leiden: Brill. (Oudtestamentische Studiën, 51.)

BOTHA, P.J. 2005. The ideological interface between Psalm 1 and Psalm 2. Old Testament essays, 18(2):189-203.

BRUEGGEMANN, W. 1991. Bounded by obedience and praise: the psalms as canon. Journal for the study of the Old Testament, 50:63-92.

BRUEGGEMANN, W. 1993. Response to James L. Mays: The question of context. (In McCann, J.C., ed. The shape and shaping of the Psalter. Sheffied: JSOT. p. 29-41.) (JSOT Supplement.)

BRUEGGEMANN, W. 2002. Spirituality of the psalms. Minneapolis: Fortress.

DE KLERK, B.J. \& JANSE VAN RENSBURG, J.J. 2005. Preekgeboorte: 'n handleiding vir gereformeerde eksegese en prediking. Noordbrug: Potchefstroomse Teologiese Publikasies.

DE KLERK, B.J. \& SMIT, E.J. 2002. Pneuma en nous in die gereformeerde kerklied: perspektiewe uit 1 Korintiërs14:15 en die tradisie, toegespits op die musiek en poësie van die kerklied. In die Skriflig, 36(1):105-124.

DE KLERK, J.J. 1977. Prediking. Pretoria: NG Kerkboekhandel.

DE WET, F.W. 2009. Die predikant as bedienaar van die Woord. Die Kerkblad, 111(3220):28-29.

GREIDANUS, S. 1970. Sola Scriptura: problems and principles in preaching historical texts. Toronto: Wedge Publishing Foundation.

GREIDANUS, S. 1999. Preaching Christ from the Old Testament: a contemporary hermeneutical method. Grand Rapids: Eerdmans.

HELBERG, J.L. 2005. Geïntegreerdheid van die psalms volgens die verband tussen Psalm 1 (en 2) en die res van die psalms. In die Skriflig, 39(4):673694.

KRATZ, R.G. 1996. Die Tora Davids. Zeitschrift für Theologie und Kirche, 93:134. 
KRAUS, H.J. 1972. Psalmen. Neukirchen-Vluyn: Neukirchen Verlag. (Biblischer Kommentar, 1.)

KRUGER, F.P. \& VENTER, C.J.H. 2002. Die prediker as toeruster van die gemeente: basisteoretiese perspektiewe vanuit Hebreërs. In die Skriflig, 36(3):349-367.

LEUSCHNER, F.W. \& DE KLERK, B.J. 2007. Basisteoretiese beginsels vir atmosfeer in die erediens afgelei uit 1 Korintiërs 11:17-14:40. In die Skriflig, 41(2):259-279.

LOMBAARD, C.J.S. 1999. By implication: didactical strategy in Psalm 1. Old Testament essays, 12(3):506-514.

LORETZ, O. 2002. Psalmstudien: Kolometrie, Strophik und Theologie ausgewählter Psalmen. Berlin: De Gruyter. (Beihefte ZAW, 309.)

McCANN, J.C. 1992. The psalms as instruction. Interpretation, 46:117-128.

MILLER, P.D. 1986. Interpreting the psalms. Philadelphia: Fortress.

MILLER, P.D. 1993. The beginning of the Psalter. (In McCann, J.C., ed. The shape and shaping of the Psalter. Sheffield: JSOT. p. 83-92.)

OESTERLEY, W.O.E. 1959. The psalms. London: SPCK.

PRINSLOO, W.S. 1984. Van kateder tot kansel: 'n eksegetiese verkenning van enkele psalms. Pretoria: NG Kerkboekhandel.

REINDL, J. 1981. Weisheitliche Bearbeitung von Psalmen: ein Beitrag zum Verständnis der Sammlung des Psalters. (In Emerton, J.A., ed. Congress volume, Vienna, 1980. Leiden: Brill. p. 333-356.) (Supplement to Vetus Testamentum, 32.)

RIDDERBOS, J. 1955. De Psalmen. Vol. 1: Psalmen 1-41. Kampen: Kok. (Commentaar op het Oude Testament.)

RÖSEL, C. 1999. Die messianische Redaktion des Psalters: Studien zu Entstehung und Theologie der Sammlung Psalm 2-89. Stuttgart: Calver.

SAEBE, E. 1971. Glücklich preisen. (In Jenni, E. \& Westermann, C., Reds. Theologisches Handwörterbuch zum Alten Testament. N.1. München: Kaiser. S. 258-259.)

SEYBOLD, K. 1998. Studien zur Psalmenauslegung. Stuttgart: Kohlhammer.

SNYMAN, S.D. 2007. Suffering in post-exilic times - investigating Maleagi 3:1324 and Psalm 1. Old Testament essays, 20(3):786-797.

STYGER, P. \& HUMAN, D.J. 2004. 'n Moontlike interpretasie van Psalm 40: Gerald $\mathrm{H}$. Wilson se navorsing oor die samehang van die Psalmbundel. In die Skriflig, 38(2):291-309.

TAYLOR, W.R. 1955. The book of Psalms. (In Buttrick, G.A., ed. The interpreter's Bible. Vol. 4. New York: Abingdon. p. 3-763.)

TOOMBS, L.E. 1971. The Psalms. (In Laymon, C.M., ed. The interpreter's onevolume commentary on the Bible. London: Collins. p. 253-303.)

TOURNAY, R.J. 1991. Seeing and hearing God with the psalms. Sheffield: JSOT. (Journal for the study of the Old Testament. Supplement Series, 118.)

VENTER, C.J.H. 2001. Verklarende (expository) prediking - 'n herevaluering. In die Skriflig, 31(4):513-536.

VENTER, C.J.H. 2004. Die Woord van God - toepaslik preek of toepaslik maak? 'n Homiletiese ondersoek. In die Skriflig, 38(4):473-493.

WEBER, B. 2006. Psalm 1 and its function as a directive into the Psalter and towards a Biblical theology. Old Testament essays, 19(1):237-260.

WEBER, B. 2008. Makarismus und Eulogie in Psalter. Old Testament essays, 21(1):193-218. 
WHYBRAY, N. 1996. Reading the Psalms as a book. Sheffield: Sheffield Academic Press. (Journal for the study of the Old Testament. Supplement Series, 222.)

WILSON, G.H. 1992. The shape of the psalms. Interpretation, 46:129-142.

ZENGER, E. 2000. Psalmenforschung nach Hermann Gunkel und Sigmund Mowinckel. (In Lemaire, A. \& Saebo, M., eds. Congress volume, Oslo, 1998. Leiden: Brill. p. 399-435. (Supplement to Vetus Testamentum, 80.)

\section{Kernbegrippe:}

gereformeerde prediking

lewensvreugde

Psalm 1

\section{Key concepts:}

joy of living

Psalm 1

reformed preaching 
